\title{
Personality beliefs as a predictor of smartphone addiction
}

\author{
Cemaliye DirektöR ${ }^{1}$ \\ https://orcid.org/0000-0002-6055-2224
}

CAHIT NURI ${ }^{2}$

https://orcid.org/0000-0002-8926-2984

1 Psychology Department, European University of Lefke, Lefke, Cyprus

${ }^{2}$ Special Education Department, Cyprus International University, Nicosia, Cyprus.

Received: 09/07/2018 - Accepted: 04/06/2019

DOI: 10.1590/0101-60830000000195

\begin{abstract}
Objective: The purpose of this study is to determine the relation between smart phone addiction and personality beliefs of university students. Methods: A total of 1007 students, 637 females (63.3\%) and 370 males (36.7\%) participated in the study. "Smart phone addiction scale short form" was used to measure smart phone addiction and "personality beliefs scale" was used to identify personality beliefs. Results: According to the performed multiple regression analysis, it was found out that dependent, antisocial, narcissist, histrionic, borderline, paranoid personality, schizoid personality, obsessive compulsive personality, passive-aggressive personality and avoidant personality beliefs predicted smart phone addiction at significant level $(\mathrm{R}=0.38, \mathrm{R} 2=0.15, \mathrm{p}<0.001)$. The mentioned variables explain $15 \%$ of the variance. An examination of the $t$-test shows that dependent personality $(t=5.585, p<0.001)$, passive-aggressive personality $(t=-4.485$, $\mathrm{p}<.001)$ and paranoid personality $(\mathrm{t}=2.901, \mathrm{p}<.01)$ belief among the mentioned variables are a significant predictor of smart phone addiction. Discussion: The obtained results show that dependent, passive-aggressive and paranoid personality beliefs are a significant predictor of smart phone addiction. Research findings are discussed in the light of relevant literature.
\end{abstract}

Direktör C et al. / Arch Clin Psychiatry. 2019;46(3):61-5

Keywords: Smart phone addiction, cognition, personality beliefs, university students.

\section{Introduction}

Smart phone usage which increased with rapid development of technology has become an essential part of life ${ }^{1}$. Smart phones are defined as a combination of computer systems with telephone system. The popularity of social networking sites which have become essential economic markets has an essential role to play in the development of smart phones. At this point, the examination of sociological dimensions of smart phone usage gains importance ${ }^{2}$. There are several studies on internet usage and relevant problems. Smart phone and social media usage reflects the personality features of individuals ${ }^{3}$. A study conducted on Facebook users said that narcissist people performed more photograph sharing and situation update ${ }^{4}$. The study conducted by Correa et al..$^{5}$ concluded that anxious people spent more time in Facebook. Similarly, it is seen that there is a relation between Facebook usage frequency and narcissist personality ${ }^{6}$. Depending on usage frequency, psychiatric diagnosis criteria also changed and "abuse and addiction of substance" in DSM-5 was replaced by "substance usage and addiction disorders" category which is now including behavioural addictions. As the case in substance addiction, repetitive behaviours, degeneration of functionality, distancing from real world, tolerance development and deprivation symptoms are among behavioural addiction criteria ${ }^{7}$. Smart phone addiction is a relatively new phenomenon; thus, very few studies define the symptoms of this type of addiction ${ }^{8}$. Repetitive behavioural disorders which affect the functionality in daily life and interpersonal relations have to be examined from the perspective of addiction concept ${ }^{9}$. with this change in DSM-5, the concept of addiction which only referred to the disorders related to substances in the past cover whole behaviors not related to substances at present. In DSM-5 the only disorder not related to substances is "gambling disorder"; however, it is stated that clinic studies in the future can evaluate gaming addiction on internet as an independent diagnosis category ${ }^{10}$. In order to be able to evaluate pathological situations such as shopping, sexuality, exercise, solarium, internet and smart phone addiction which stimulate rewarding system and progress using repetitive and compulsive behavior patterns within the scope of DSM and to determine diagnosis criteria, studies which will help display constant and repetitive usages of these disorders which can degenerate functionality are needed ${ }^{9}$. Repetitive behaviors lie in the foundation of behavioral addictions. Behaviors which give pleasure to individuals produce behaviors and lead to habitual situations ${ }^{11}$. For this reason, one has to be very careful when evaluating a behavior which became habit as an addictive behavior. Similar to other areas of addiction, excessive dealing with a certain behavior and repeating these behaviors in order to create an emotion in order to become distant from the real world and reveal an emotion which makes oneself feel better ${ }^{12}$, development of tolerance as behaviors are repeated, difficulty in controlling behaviors, repetition of behavior, emergence of such withdrawal findings as tension, irritability, and unrest, and proceeding of behaviors at an increasing rate lead to the degeneration of functionality ${ }^{13}$. Although smart phone addiction has not been defined clearly yet, it mostly emerges with such symptoms as not being able to be away from the phone, controlling the phone frequently, insomnia due to excessive usage of the phone and distortion of sleeping quality ${ }^{14}$.

It is reported that $64 \%$ of America is smart phone user $46 \%$ of which is problematic users ${ }^{15}$. Studies conducted on smart phone addiction displayed that it is related to such variables as loneliness, narcissist personality and low self-esteem ${ }^{16}$. In addition to claiming an importance place in the lives of individuals as social interaction tools, using smart phones to spend more time in social networking sites reduces student success ${ }^{17}$. In addition, it is also stated that it is related to individuals suffering from more negative feelings ${ }^{18}$. It is reported that personality extroversion dimension predicts smart phone addiction ${ }^{19}$.

Personality is defined as characteristic features and static qualifications in tendencies; it appears as the fundamental element 
which determines the feelings, opinions and behaviours of the individual ${ }^{20}$. Despite their different viewpoints, theories defining personality agree that personality covers cognitive, emotional, social and physical areas ${ }^{21}$. Cloninger and Svrakic ${ }^{22}$ mention the environmental-adaptation effect of personality. Personality has bene explained by several theories and disorders are based on the explained theory. It is reported that in addition to biological construction, psychosocial factors are also essential in the formation of personality disorders ${ }^{23}$. Cognitive approach explains personality development of a person with the beliefs developed in childhood. It is argued that the functionality of these beliefs is effective in the formation of personality disorder. According to cognitive approach, every disorder has unique non-functional beliefs ${ }^{24}$. A person with narcissist personality disorder believes that he/she has a very essential place in the society whereas another person with paranoid disorder believes that other people will harm him/her. Examination of cognitive structures of a person displays the personality characteristics of that person ${ }^{25}$. Cognitive theory deals with the belief dimension of personality whereas it explains personality disorders with non-functional beliefs ${ }^{24}$. Basic beliefs shaped by the experiences of the individual direct his/her emotions and behaviours ${ }^{26}$. Beliefs which are activated with an experience affect the experience of the individual negatively if they are not functional27. The purpose of this study is to determine the relation between smart phone addiction of university students and their personality beliefs.

\section{Methods}

\section{Model of the study}

This study is a survey research on the prediction of impact of personality beliefs on smart phone addiction. In scanning model studies, effort is paid to describe an existing situation as it is ${ }^{28}$. Scanning model is a model which can be used without affecting the processes which exist in the institutions included in the study sample during the study. One advantage of the scanning model is that it can be used without distorting the existing order in the studied institution and without creating any difficulty for the personnel of the institution ${ }^{29}$. The purpose in correlation studies is to examine the relation between two or more variables without interfering these variables in any way ${ }^{30}$.

\section{Study group}

There are 38 universities in total in Northern Cyprus 23 of which are active. According to the report published by the Ministry of National Education of Turkish Republic of Northern Cyprus (TRNC) 93,232 students are receiving education and teaching at TRNC universities. Of these students, 52,135 are TC nationals, 27,538 are foreign nationals coming outside Republic of Turkey, and 13,619 are TRNC nationals ${ }^{31}$. The total population of country nationals is known as 230,74732 . Despite having a small population, this number reaches 650 thousand with the number of university students. Due to the low level of exports and high level of imports, the country economy is among developing countries. In addition, TRNC is not officially recognized by other countries. Despite all these shortcomings, it is still being promoted as a university country. In several universities opened, the largest group of students is represented by education faculties. This study is also conducted with education faculty students. Data were collected in a web-based manner in order to reach more people in a short time. The link created in Google form was shared with the WhatsApp groups of various universities. Information was given to Education Faculty students who studied at a private university in Northern Cyprus and questionnaires were applied to voluntary students in virtual environment. A total of 1,007 students, 637 females (63.3\%) and 370 males (36.7\%) participated in the study.

\section{Data collection tools}

Sociodemographic information form: The form which was prepared by the researcher according to the purpose of the research, questions for receiving information on participants such as age and gender are included.

Smart phone addiction scale short form: The scale developed by Kwon et al. ${ }^{33}$ consists of 10 items in total. Its adaptation to Turkish language was conducted by Noyan et al. ${ }^{34}$. The study conducted by the researchers reports that the scale has a single-factor structure which explains $46.3 \%$ of the total variance. The internal consistency coefficient of the scale is given as .87 whereas test-retest reliability coefficient is given as .98. For this study, Cronbach alpha value has been found as 97 .

Personality belief scale: The scale which consists of 126 items has 9 personality beliefs, namely timid, dependent, passive aggressive, obsessive compulsive, antisocial, narcissistic, histrionic, schizoid and paranoid attitudes. The scale aims at determining the basic beliefs of the individual about himself, others and the world. The reliability and validity study of the scale was conducted by Türkçapar et al.24. Reliability internal consistency coefficient was found as .95 in adaptation study. For this study, Cronbach Alpha value was found as .93. Reliability coefficient was calculated using Cronbach Alpha for the sample and was found as .91 .

\section{Analysis of data}

The data obtained from the study were entered with SPSS 20 package programme. Multiple regression analysis was used in line with the purpose of the study.

\section{Results}

It has been found out that $35 \%$ of participants received scores above 31 which is the cutoff score defined by Kwon et al. According to the obtained results, it has been found out that smart phone addiction scores do not show significant difference depending on gender $(\mathrm{p}=0.221)$.

It has been observed that there is a low and significant relation (Table 1$)$ between dependent personality $(\mathrm{r}=0.332, \mathrm{p}<0.001)$, narcissist personality $(\mathrm{r}=0.265, \mathrm{p}<0.001)$, antisocial personality $(\mathrm{r}=0.237, \mathrm{p}<0.001)$, paranoid personality $(\mathrm{r}=0.245, \mathrm{p}<0.001)$, borderline personality $(\mathrm{r}=0.246, \mathrm{p}<0.001)$, histrionic personality $(\mathrm{r}=0.258, \mathrm{p}<0.001)$, schizoid personality $(\mathrm{r}=0.161, \mathrm{p}<.001)$, obsessive compulsive personality $(\mathrm{r}=0.135, \mathrm{p}<.001)$, passiveaggressive personality $(\mathrm{r}=0.086, \mathrm{p}<.01)$ and avoidant personality $(\mathrm{r}=0.131, \mathrm{p}<.001)$ beliefs and smart phone addiction scores. Another finding is that the relation between dependent personality beliefs and smart phone addiction is significant at higher level compared to other personality beliefs. There are research findings in the literature which show that addiction is in relation with impulsivity. When the findings of the study are examined, it has been that there is relation between antisocial, histrionic, and narcissist personality, which are in $\mathrm{B}$ category, and smart phoned addiction. It is known that individuals in this category act more impulsively than other groups.

Table 1. Relation between personality beliefs and smart phone addiction

\begin{tabular}{|l|c|}
\hline Smart phone addiction & Correlation values \\
\hline Dependent personality & $0.332^{* * *}$ \\
\hline Narcissist personality & $0.265^{* * *}$ \\
\hline Antisocial personality & $0.237^{* * *}$ \\
\hline Paranoid personality & $0.245^{* * *}$ \\
\hline Borderline personality & $0.246^{* * *}$ \\
\hline Histrionic personality & $0.258^{* * *}$ \\
\hline Schizoid personality & $0.161^{* * *}$ \\
\hline Obsessive compulsive personality & $0.135^{* * *}$ \\
\hline Passive-aggressive personality & $0.086^{* *}$ \\
\hline Avoidant personality & $0.131^{* * *}$ \\
\hline
\end{tabular}

\footnotetext{
${ }^{* *} \mathrm{p}<.01 ;{ }^{* * *} \mathrm{p}<.001$.
} 
According to the conducted multiple regression analysis (Table 2), it is found out that dependent, antisocial, narcissist, histrionic, borderline, paranoid personality, schizoid personality, obsessive compulsive personality, passive-aggressive personality and avoidant personality beliefs predicted smart phone addiction at significant level $\left(\mathrm{R}=0.38, \mathrm{R}^{2}=0.15, \mathrm{p}<0.001\right)$. The mentioned variables explain $15 \%$ of the variance. An examination of the t-test shows that dependent personality $(t=5.585, p<0.001)$, passive-aggressive personality $(\mathrm{t}=-4.485, \mathrm{p}<.001)$ and paranoid personality $(\mathrm{t}=2.901$, $\mathrm{p}<.01)$ belief among the mentioned variables are a significant predictor of smart phone addiction.

\section{Discussion}

Pew Research Centre reports that $64 \%$ of the American population is smart phone user $46 \%$ of which bears addiction risk ${ }^{15}$. Consisted with the percentage of the centre, $32 \%$ of the participants of this study were found to be subject to smart phone addiction risk. There are research findings which show that smart phone addiction is more widespread among males ${ }^{16}$. However, in this research, it is found out that gender variable did not create any significant difference in smart phone addiction scores. It is believed that this difference is caused by cultural variables. Possession, accessibility and usability of smart phones is part of daily life at similar levels for both genders.

Loneliness, narcissist characteristics, low self-esteem are among the variables which can affect smart phone addiction ${ }^{16}$. In this study, the predictor impact of personality beliefs on smart phone addiction has been examined. At the end of the study, it has been observed that dependent, narcissist, histrionic, borderline, antisocial and paranoid personality beliefs predict smart phone addiction positively and at significantly. As regards prediction of smart phone addiction, it was found out that dependent personality characteristic was significant. The study of Butt and Phillips ${ }^{3}$ reported that personality features are predictor of smart phone addiction. It is expected that the two variables are related considering that personality features reflect the emotions and behaviours of the individual. On the other hand, there are findings in the literature that narcissist features are the most related ones with smart phone addition or social media addiction. However, in this study it became noticeable that dependent personality belief is a significant predictor of smart phone addiction. According to cognitive behavioural approach, every personality has a non-functional fundamental belief ${ }^{26}$. Individuals with dependent personality belief are in intense need of another for their individual lives. It is very difficult for them to exist in the absence of another person. At this point, the "other" of individuals with dependent personality to whom they are dependent is replaced by smart phones. Individuals with paranoid personality characteristics are thought to have received more smartphone addiction scores in relation to having a thought of persecution. In addition, the persons who have passive- aggressive personality beliefs reflected their aggressive emotions through smartphone. It is known that individuals with dependent and passive aggressive personality beliefs display submissive behaviour before authority. Individuals with paranoid personality beliefs also have important difficulties with authority; however, unlike dependent and passive-aggressive, they use projectional defense mechanism ${ }^{26}$ and believe that what is unreliable is the external object. The common feature of these three personality beliefs is that they have problems with confidence and authority. Individuals with dependent personality belief have higher levels of addiction. Smartphone addiction has to be distinguished from substance addictions. Technology has improved rapidly and cyber-spaces which present unlimited information caused the daily life to be carried to the virtual space. As a result, the distinction between a living thing and an artificial thing disappeared and the boundaries of personality vanished. As a result of such alienation, the search for meeting the needs in objective work disappeared. When one starts with an identity in virtual reality, the unacceptable and suppressed dimension of the personality turns the different, meaning virtual reality into a virtual ID and hides it from reality; the suppressed side also has the opportunity of continuing its existence ${ }^{35}$. It also keeps off the real life anxieties caused by the rejection of desires. Thus, an action which is not performed in reality is not a source of shame. It offers the person freedoms which are idealized, do not generate anxiety, allows for creation and can be hidden as desired. It hides the unacceptable drives of the person and provides satisfaction in the created virtual environment, which is related to negative emotions ${ }^{36}$. In this way, the level of addiction of individuals for smart phones increases which are essential tools in reaching the virtual environment where they can freely express their drives.

In accordance with the obtained results, it was found out that dependent, passive-aggressive and paranoid personality beliefs predicts smart phone addiction. Future studies should examine such intermediate variables as loneliness, relationship satisfaction and social support perception which can be related to dependent personality and smart phone addiction which would enrich knowledge on smart phone addiction. This study covered participants with similar characteristics. It is believed that studies with different age groups and individuals with different characteristics will make essential contribution to the field.

\section{Ethic statement}

This study was carried out in accordance with the recommendations from European University of Lefke with written informed consent from all participants. All participants gave written informed consent in accordance with the Declaration of Helsinki. The protocol approved by Head of the Psychology Department of European University of Lefke.

Table 2. Multiple-regression results as regards the prediction of smart phone addiction

\begin{tabular}{|c|c|c|c|c|c|c|}
\hline Predicted variable & Predicting variables & B & Standard error & Beta & $t$ & $p$ \\
\hline \multirow[t]{11}{*}{ Smart phone addiction } & Constant & 25.545 & 0.883 & & 28.945 & \\
\hline & Dependent & 0.312 & 0.056 & 0.279 & 5.585 & $.000^{* * *}$ \\
\hline & Antisocial & 0.075 & 0.047 & 0.071 & 1.602 & .110 \\
\hline & Narcissist & 0.099 & 0.057 & 0.082 & 1.749 & .081 \\
\hline & Histrionic & 0.040 & 0.049 & 0.036 & 0.822 & .411 \\
\hline & Borderline & -0.055 & 0.063 & -0.046 & -0.875 & .382 \\
\hline & Paranoid & 0.162 & 0.056 & .144 & 2.901 & $.004^{* *}$ \\
\hline & Schizoid & 0.101 & 0.052 & 0.076 & 1.926 & .054 \\
\hline & $\begin{array}{c}\text { Obsessive } \\
\text { compulsive }\end{array}$ & -0.062 & 0.056 & -0.044 & -1.094 & .274 \\
\hline & Passive-aggressive & -0.262 & 0.058 & -0.189 & -4.485 & $.000 * * *$ \\
\hline & Avoidant & -0.102 & 0.061 & -0.068 & -1.675 & .094 \\
\hline
\end{tabular}




\section{Conflict of interest}

Nothing to declare.

\section{Acknowledgments}

The authors would like to thank participants involved for contributing to the study and making this study possible.

\section{References}

1. Bozkurt İ. Psikolojik Yardım Uygulamalarında Yeni Trend: Online Terapiler [New Trend in Psychological Help Applications: Online Therapies]. Int J Hum Sci. 2013;110:130-46.

2. Balick A. The Psychodynamics of Social Networking: Connected-up Instantaneous Culture and the Self. Psychoanalysis and Popular Culture. London: Karnac Books; 2013.

3. Butt S, Phillips JG. Personality and self-reported mobile phone use. Comput Human Behav. 2008;24(2):346-60.

4. Carpenter CJ. Narcissism on Facebook: Self-promotional and anti-social behavior. Personality and Individual Differences. 2012;52(4):482-6.

5. Correa T, Hinsley AW, De Zuniga HG. Who interacts on the Web?: The intersection of users' personality and social media use. Comput Human Behav. 2010;26(2):247-53.

6. Mehdizadeh S. Self-presentation 2.0: Narcissism and self-esteem on Facebook. Cyberpsychol Behav Soc Netw. 2016;13(4):357-64.

7. American Psychiatric Association. Diagnostic and Statistical Manual of Mental Disorders 5. Washington, DC: American Psychiatric Association Publishing; 2013

8. Kim D, Lee Y, Lee J, Nam JK, Chung Y. Development of Korean Smartphone Addiction Proneness Scale for Youth. PloS One. 2014;9(5):e97920.

9. Grant JE, Potenza MN, Weinstein A, Gorelick DA. Introduction to behavioral addictions. Am J Drug Alcohol Abuse. 2010;36(5):233-41.

10. Nurmedov S. Psikiyatride Güncel - Davranışsal Bağımlılıklar, Akıllı telefon bağımlılığında tanı ve tedavi J Psychiatric Asso Turkey for Continuing Education/Continuing Professional Develop, 2013; 252-260.

11. Oulasvirta A, Rattenbury T, Ma L, Raita E. Habits make smartphone use more pervasive. Pers Ubiquitous Comput. 2012;16:105-14.

12. Chakraborty K, Basu D, Kumar KG. Internet addiction: consensus, controversies, and the way ahead. East Asian Arch Psychiatry. 2010;20(3):123-32.

13. Wu AM, Cheung VI, Ku L, Hung EP. Psychological risk factors of addiction to social networking sites among Chinese smartphone users. J Behavioral Addic. 2013;2(3):160-6.

14. Kuyucu M. Gençlerde akıllı telefon kullanımı ve akıllı telefon bağımlılığı sorunsalı: "Akıllı Telefon (Kolik)" Üniversite Gençliği. Global Media Journal TR Edition. 2017;7(14):328-59.

15. Pew Research Center. The Smartphone Difference. 2015. Available from: http://www.pewinternet.org.

16. Darcin AE, Kose S, Noyan CO, Nurmedov S, Yilmaz O, Dilbaz N. Smartphone addiction and its relationship with social anxiety and loneliness. Behav Inform Tech. 2016;35:520-5.

17. Kirschner PA, Karpinski AC. Facebook and Academic Performance. Comput Human Behav. 2010;26:1237-45.

18. Hew KF. Students' and teachers' use of Facebook. Comput Human Behav. 2011;27(2):662-76.
19. Lane W, Manner C. The impact of personality traits on smartphone ownership and use. Int J Business Soc Sci. 2011;2:17.

20. Maddi SR. Personality theories: a comparative analysis. 5th ed. Homewood, IL: Dorsey; 1989.

21. Ewen RB. An introduction to theories of personality. Mahwah, NJ Lawrence Erlbaum Associates; 2003.

22. Cloninger CR, Svrakic DM. Personality disorders. In: Sadock BJ, Sadock VA, eds. Kaplan and Sadock's: Comprehensive Textbook of Psychiatry. 7th ed. Philadelphia: Lippincott Williams \& Wilkins; 2000.

23. American Psychiatric Association. Diagnostic and Statistical Manual of Mental Disorders. 4th ed. Washington DC: American Psychiatric Association; 1994

24. Türkçapar MH, Örsel S, Uğurlu M, Sargın E, Turhan M, Akkoyunlu S, et al. Personality belief Scale Validity and Reliability of Turkish Form. Clin Psychiatry. 2007;10:177-91.

25. Beck AT, Beck JS. The Personality Belief Questionnaire. Unpublished assessment instrument. The Beck Institute for Cognitive Therapy and Research. Pennsylvania: Bala Cynwyd; 1991.

26. Taymur İ, Türkçapar MH. Personality: description, classification and evaluation. Psikiytr Gün Yak. 2012;4(2):154-77.

27. Hjemdal O, Stiles T, Wells A. Automatic thoughts and meta-cognition as predictors of depressive or anxious symptoms: a prospective study of two trajectories. Scand J Psychol. 2013;54(2):59-65.

28. Karasar N. Bilimsel araştırma yöntemi: kavramlar-ilkeler-teknikler Ankara: Nobel Yayın Dağitim; 2008.

29. Köse E. Bilimsel araștırma modelleri. Bilimsel Araștırma Yöntemleri Kitab1, Edi: Kıncal RY. Ankara. Nobel Yayıncilı; 2013.

30. Büyüköztürk Ş, Akgün ÖE, Çakmak E, Demirel F, Karadeniz Ş. Bilimsel Araştırma Yöntemleri (7th). Ankara: Pegem Akademi Yayın Dağıtım; 2010.

31. KKTC Milli Eğitim ve Kültür Bakanliği. 2016-2017 Öğretim Yılında KKTC Üniversitelerinde Eğitim ve Öğretim Gören Öğrenci Sayıları. Available from: http://www.mebnet.net/?q=content/20162017 - \% C3\%B6\%C4\%9Fretim-y\%C4\%B 11\%C4\%B 1nda-kktc$\%$ C3\%BCniversitelerinde-e\%C4\%9Fitim-ve-\%C3\%B6\%C4\%9Fretimg\%C3\%B6ren-\%C3\%B6\%C4\%9Frenci-say\%C4\%B 1lar\%C4\%B1. Accessed on: 17 Oct. 2018.

32. TRNC Prime Ministry State Planning Organization. Statistical Yearbook 2017. Available from: http://www.devplan.org/Ist_yillik/ISTYILLIK-2017.pdf. Accessed on: 21 Oct. 2018.

33. Kwon M, Lee JY, Won WY, Park JW, Min JA, Hahn C, et al. Development and validation of a Smartphone Addiction Scale (SAS). PLoS One. 2013;8(2):e56936

34. Noyan CO, Enez Darçın A, Nurvedov S, Yılmaz O, Dilbaz N. Reliability and validity in Turkish of Smart Phone Addiction Scale Short Form on university students. Anatolian Journal of Psychiatry/Anadolu Psikiyatri Dergisi. 2015;16:73-81.

35. Dönmez OS. Arayüzde büyü(len)mek: bilișim teknolojisi ve ruhsal gelişim ilişkisi üzerine psikanalitik bir bakış. Psikanaliz YazılarıPsikanaliz ve Okul, Baharlık Kitap Dizisi-İstanbul: Bağlam Yayınları. 2011; 22: 103-112.

36. Ybarra ML, Mitchell KJ. "Sexting" and its relation to sexual activity and sexual risk behavior in a national survey of adolescents. J Adolesc Health. 2014;55(6):757-64. 


\section{Appendix}

Akilli Telefon Bağimliliği Ölçeği-Kisa Form (Smartphone Addiction Scale-Short Form)

Yönerge: Aşağida akilli telefon kullanimi ile ilgili çeşitli duygu ve düşünceleri içeren anlatimlar verilmiştir. Lütfen her anlatimin size ne kadar uyduğunu değerlendirerek en uygun seçeneği yuvarlak içine aliniz.

1. Kesinlikle katilmiyorum (Strongly disagree); 2. Katilmiyorum (Diasagree); 3. Kismen katilmiyorum (Slightly disagree); 4. Kismen katiliyorum (Slightly agree); 5 . Katiliyorum (Disagree); 6. Kesinlikle katiliyorum (Strongly agree)

\begin{tabular}{|c|c|c|c|c|c|c|}
\hline $\begin{array}{l}\text { TR: Akilli telefon kullanmaktan dolayi planladiğim işleri aksatirim. } \\
\text { ENG: Missing planned work due to smartphone use. }\end{array}$ & 1 & 2 & 3 & 4 & 5 & 6 \\
\hline $\begin{array}{l}\text { TR: Akilli telefonu kullanmaktan dolayi derslerime odaklanmakta, ödevlerimi yapmakta ve işlerimi tamamlamakta güçlük çekerim. } \\
\text { ENG: Having a hard time concentrating in class, while doing assignments, or while working due to smartphone use. }\end{array}$ & 1 & 2 & 3 & 4 & 5 & 6 \\
\hline $\begin{array}{l}\text { TR: Akilli telefon kullanmaktan dolayi el bileğimde veya ensemde ağri hissederim. } \\
\text { ENG: Feeling pain in the wrists or at the back of the neck while using a smartphone. }\end{array}$ & 1 & 2 & 3 & 4 & 5 & 6 \\
\hline $\begin{array}{l}\text { TR: Akıllı telefonumun yanımda olmamasına tahammül edemem. } \\
\text { ENG: Won't be able to stand not having a smartphone. }\end{array}$ & 1 & 2 & 3 & 4 & 5 & 6 \\
\hline $\begin{array}{l}\text { TR: Akilli telefonum yanimda olmadiğinda sabirsiz ve sinirli olurum. } \\
\text { ENG: Feeling impatient and fretful when I am not holding. }\end{array}$ & 1 & 2 & 3 & 4 & 5 & 6 \\
\hline $\begin{array}{l}\text { TR: Kullanmasam da, akilli telefonum aklimdadir. } \\
\text { ENG: Having my smartphone in my mind even when I am not using it. }\end{array}$ & 1 & 2 & 3 & 4 & 5 & 6 \\
\hline $\begin{array}{l}\text { TR: Günlük yaşamimi aksatmasina rağmen akilli telefonumu kullanmaktan vazgeçemem. } \\
\text { ENG: I will never give up using my smartphone even when my daily life is already greatly affected by it. }\end{array}$ & 1 & 2 & 3 & 4 & 5 & 6 \\
\hline $\begin{array}{l}\text { TR: Insanlarin twitter veya facebook üzerindeki konuşmalarini kaçirmamak için sürekli akilli telefonumu kontrol ederim. } \\
\text { ENG: Constantly checking my smartphone so as not to miss conversations between other people on Twitter or Facebook. }\end{array}$ & 1 & 2 & 3 & 4 & 5 & 6 \\
\hline $\begin{array}{l}\text { TR: Akilli telefonumu hedeflediğimden daha uzun süre kullanirim. } \\
\text { ENG: Using my smartphone longer than I had intended. }\end{array}$ & 1 & 2 & 3 & 4 & 5 & 6 \\
\hline $\begin{array}{l}\text { TR: Çevremdeki insanlar akilli telefonumu çok fazla kullandiğimi söylerler. } \\
\text { ENG: The people around me tell me that I use my smartphone too much. }\end{array}$ & 1 & 2 & 3 & 4 & 5 & 6 \\
\hline
\end{tabular}

